JELTL (Journal of English Language Teaching and Linguistics)

e-ISSN: 2502-6062, p-ISSN: 2503-1848

Year, Vol. 5(2)

www.jeltl.org

\title{
The Dominant Speech Functions in Cigarette Billboard Texts
}

\author{
Muhammad Hasyimsyah Batubara \\ IAIN Gajah Putih Takengon Aceh Tengah, Aceh \\ e-mail: muhammad.hasyimsyahbatubara@gmail.com \\ Dina Syarifah Nasution \\ STAIN Mandailing Natal Sumut \\ e-mail: dinasyarifahnasution1982@gmail.com
}

\begin{abstract}
This research related to speech functions in cigarette billboard texts. The objectives are to describe the category and to derive dominantly used and explain the factors of the phenomenon of speech functions. The research method used descriptive qualitative. Data was collected by applying documentary techniques from commercial cigarette billboard texts (headline, subhead, slogan and images) in public places around the city center of Medan. The finding describes of the four speech functions available only three are used in commercial cigarette billboard text, statement constitutes 18 (69.25\%), question 1 (3. $8 \%$ ), command 7 (26. 9\%), and offer 0 from 26 billboard texts. Statement genre used as the dominant one because it is suitable with the pattern of commercial billboard texts, where the viewer assumed only briefly saw the display of images and written text of the billboard with a duration of 5-7 seconds when they were driving. Thus, simple and powerful information in speech function of functional grammar and the language used must be efficient, effective and able to hypnotize readers so that results in positive action on the item being advertised.
\end{abstract}

Keywords: advertisement, billboards, cigarette, speech functions, text

\section{INTRODUCTION}

In the present dimension of modern society, technological advancements have touched almost the entire way society views life. The community has changed the old values of life with a new perspective. This has an impact on the birth of the consumer in shopping. These are specifically observed by producers/traders for their product marketing strategy with the use of different and unique language styles and functions so that people's unconscious minds 


\section{Muhammad Hasyimsyah Batubara \& Dina Syarifah Nasution}

are trapped with the diction seduction used. In the end, change and build positive perceptions and reactions to a product being advertised. This is where language provides an absolute role in influencing and accepting someone. Therefore the power of language plays a role in this.

In the study of language metafunctions, functions are classified into three parts: 1) ideational, 2) interpersonal, and 3) textual functions. In this discussion, research is conducted merely on interpersonal functions by reason of it is very often found in the community. The way of understanding someone's speech by means of interpersonal functions is clear by understanding the speech function used, whether in form statement, question, offer, command. According to (Halliday, 1994:30; Halliday \& Matthiessen, 2014) stated speech functions are the actions or performance done by language users as asking, commanding, and answering in order to fulfill the intention of the speakers and listener. Understanding these four speech functions will help the listener or viewer capture the meaning of speech in communication.

Actually, there are so many areas of speech function which can be used as research objects. Several studies on the speech function that the authors read are like in the education area with the title of the analysis of speech functions used by an ELESP lecturer in English for young learner class (Mahendra \& Zulham, 2020), and when low class confronts high class: an analysis of Petruk interpersonal meaning through his speech functions in Javanese performing art Kethoprak (Shanty, 2014). In other areas such as speech function and process in fake news (Fitriyani, et al, 2019). Meanwhile, similar research in the advertising study area as conducted by Dalimunte (2012) by title speech function and speech role in the advertisement on television. Another title about style and speech function on willingness to buy of Bina Nusantara university student in Garuda Indonesia inflight magazine advertisement (Cahyono and Naf'an, 2013), and research by Wahyudihardjo and Clara (2014) about presupposition and speech function in women product advertisements. Besides, this study tries out to do that on outdoor advertising. Billboards become one of the most popular outdoor media used to inform something and simple marketing strategy of promoting products or the like, billboards are growing very rapidly not only in terms of size but also in the use of language and choice of words, as well as visual aids that are very eyecatching.

Indeed, there is a phenomenon where billboards have the power to hypnotize the viewer so that the reader captures the meaning of the message in just six seconds while driving (Weir, 1993; Baack, 2007:249). This gives a challenging question about how important is the use of language in billboards to be able to hypnotize and why billboards can hypnotize readers. In fact, the questions will be clearly answered if they are related to linguistics because what is conveyed on the billboard is a text that contains the use of language studies. Based on the explanation above, the researcher is very interested in studying the use of language in the billboard text, whether the text intended to refer to statements, questions, offers, and commands named speech function in billboard texts of cigarette advertising. 


\section{REVIEW OF LITERATURE}

\subsection{Speech functions}

According to (Halliday, 1994:30; Gerot, and Wignell, 1994:22; Morley, 2000:9) stated that speech function is a performance or action by language users in the form of statement, question, offer, and command. It is applied as the means exchange the experience between speakers and listener in reserve to comply with their requirements. For example: "I read many books in the library" is the example of a statement which refers to whatever people say either positive or negative. Then, the next example is "could you start now, please?" as a request which refers to something do you want while another example is "would you like to have a tea?" as an offer which refers to an offering. Next, "open the book! It is the example of a command which refers to whatever you do.

\subsection{Statement}

Statement is the process of providing information in either a positive or negative pattern. It is named as a statement if the subject is positioned in front of a verb or auxiliary verb (Collins, 1998:96). Then, it is ended with a period (.). In addition, (Grolier, 1992) specifically the form of the statement is the process of giving or distribution information not only in speech and but also in writing. In other words, statement form is a declarative or assertive statement which is intended to provide information in spoken or written language. Table 1: Speech function as a Statement

\begin{tabular}{|c|c|c|}
\hline \multirow{3}{*}{$\begin{array}{l}\frac{\text { Formula }}{\text { Subject + verb/Aux. }} \\
\text { V }\end{array}$} & Explanation & Example \\
\hline & $\begin{array}{l}\text { Subject is positioned in front } \\
\text { of a verb or auxiliary } \\
\text { verb/modal }\end{array}$ & $\frac{\text { It }}{S} \frac{\text { builds }}{\text { Verb }}$ strong teeth. \\
\hline & & $\begin{array}{l}\frac{\text { Mobile phone }}{S} \frac{\text { is }}{A u x} \text { very useful } \\
\text { in keeping communication }\end{array}$ \\
\hline
\end{tabular}

Adapted from (Leech and Svartvik, 2003; Carter and McCarthy, 2006; Downing and Locke, 2006; Cobuild, 2011).

\subsection{Question}

A question form is a process of demanding information within the scheme of interrogative expression which inquires reply from the listener (Grolier, 1992:327). There are three types of question, such as:

1). Yes or no-question

Yes/no question can be answered with a "yes" or "no", hence the name is referred to (Leech and Svartvik, 2003; Carter and McCarthy, 2006; Downing and Locke, 2006; Cobuild, 2011).

2.) Wh-question

Wh-question uses an interrogative word to ask information. The question words are who, what, when, where, why, how which are usually ended with a question mark (?). In further, they cannot be answered only with yes or no but with meaningful information to (Leech and Svartvik, 2003; Carter and McCarthy, 2006; Downing and Locke, 2006; Cobuild, 2011). 


\section{Muhammad Hasyimsyah Batubara \& Dina Syarifah Nasution}

3.) Tag questions

Tag questions are a grammatical structure form in which a declarative or an imperative fragment (the 'tag"), such as 'right, don't you, doesn't he or etc. For example, is "He still calls his mother, doesn't he?" The tag question can be answered only with two possible answers, namely yes or no. The subject is positioned after the auxiliary verb or whquestion and then followed by verb to (Leech and Svartvik, 2003; Carter and McCarthy, 2006; Downing and Locke, 2006; Cobuild, 2011).

Table 2: Speech function as a Question

\begin{tabular}{|c|c|c|}
\hline Formula & Explanation & Example \\
\hline \multirow[t]{4}{*}{$\begin{array}{l}\text { Aux, verb or wh- } \\
\text { question }+ \text { Subject }+ \\
\text { Verb }\end{array}$} & $\begin{array}{l}\text { Subject is positioned after } \\
\text { auxiliary verb or Wh-question, } \\
\text { and then followed by verb. }\end{array}$ & $\frac{\text { Who }}{\text { Wh-Q }} \quad \frac{\text { are }}{\text { Aux }}$ you? \\
\hline & & Do you ever go to Bali? \\
\hline & & Aux $S$ \\
\hline & & He still calls his mother, doesn't he? \\
\hline
\end{tabular}

Adapted from (Leech and Svartvik, 2003; Carter and McCarthy, 2006; Downing and Locke, 2006; Cobuild, 2011).

\subsection{Offer}

An offer is a process of giving goods and services to someone. According to Collins, (1998) an offer is in general begun with attach one of the modals, then added by a subject and terminated with a question mark (?). An offer form is also interpreted as an expression of willingness to give something or to continue something for acceptance or rejection (Grolier, 1992:268).

Table 3: Speech function as Offer

\begin{tabular}{|c|c|c|}
\hline \multirow{3}{*}{\begin{tabular}{l}
\multicolumn{1}{c}{ Formula } \\
Modal+ Subject+ \\
Verb
\end{tabular}} & Explanation & Example \\
\hline & $\begin{array}{l}\text { Being started of the modals, } \\
\text { next followed by a subject } \\
\text { and verb }\end{array}$ & $\frac{\text { May }}{\text { Modal }} \stackrel{\text { I }}{S} \frac{\text { helpyou? }}{\mathrm{V}}$ \\
\hline & & $\frac{\text { Would }}{\text { Modal }} \frac{\text { you }}{\mathrm{S}} \frac{\text { like to buy this laptop? }}{\mathrm{V}}$ \\
\hline
\end{tabular}

Adapted from (Leech and Svartvik, 2003; Carter and McCarthy, 2006; Downing and Locke, 2006; Cobuild, 2011).

\subsection{Command}

A command is a process of expecting goods and services in the scheme imperative, and maybe the shape is a positive or negative command. Further, in command sentence, the subject is omitted and the basic form of verbs used (Collins, 1998). Or, it begins by the predicate, and it is generally terminated with an exclamation mark (!).

Table: 4 Speech function as a Command




Please don't smoke here!

Verb

Adapted from (Leech and Svartvik, 2003; Carter and McCarthy, 2006; Downing and Locke, 2006; Cobuild, 2011).

In further, the four types of speech functions above show their realizations in 'MOOD' which is part of interpersonal meaning in the area of lexicogrammar. The speech functions (statement, question, and command) are created by declarative, interrogative, and imperative forms. The speech of offer does not have an unmarked representation of 'MOOD' (Saragih, 2010:15). In English, the realization of speech functions is shown in figure 1.

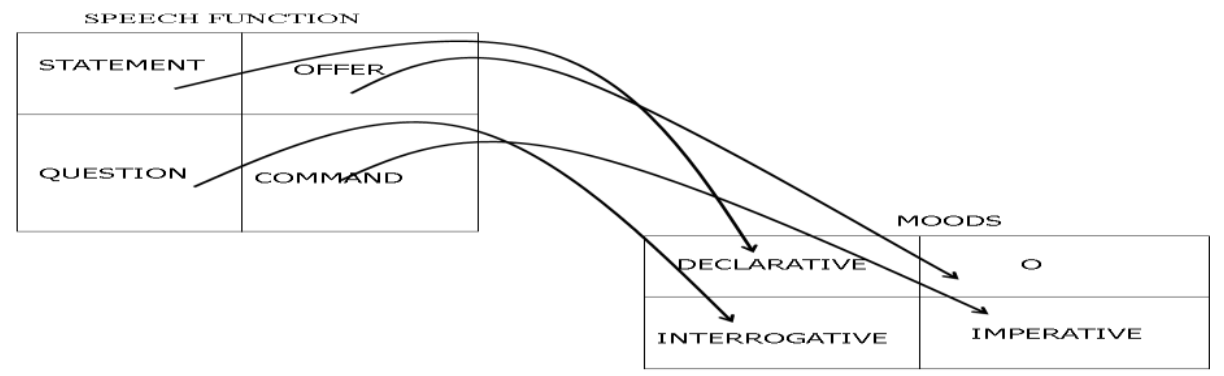

Figure: 1 Realization of Speech Functions in Mood

In addition, the speech functions and the responses Halliday (1994:69) are presented in figure 1. It shows that the semantic system can be expanded into four speech function pair choices between initiating and responding moves. The speaker initiates and interaction he assigned to the listener to put into the role of responding. The speech function pairs can be between initiating and responding (+) or (-); occasionally offer (accept or reject), statement at times (acknowledge or contradict), command sometimes (undertaken or refuse, and question (answer or disclaim).

\subsection{Advertisement}

In general, advertisement is a means of a company to promote goods, services, companies, and ideas by an identified sponsor and overall promotional strategy. As a result, it will be connected with some components such as publicity, public relations, personal selling, and sales promotion. In addition, Jefkins (1994:15) stated that advertisements or usually written ads are the ones of special communication for marketing function in running the marketing function. Advertisement not only just gives information but also attracts publics' attention. Thus, the main purpose of the advertisement is how the advertisement can persuade the consumer so that they will consume it later (Cook, 1992; Bex, 1996; Adelaar, et al., 2003; (Abideen \& Latif, 2011). It means that the advertisement should lead the public attention to buy the product or service which has been arranged well. 


\section{Muhammad Hasyimsyah Batubara \& Dina Syarifah Nasution}

In fact, the advertisement is not only can be seen in billboards but also in many other things. Jonathan (1999) uttered that advertisement is everywhere on television, radio, newspaper, magazine, hoarding, mailboxes, trains, buses, internet, etc. The advertisement has two categories, namely commercial advertisement and public service advertisement known as non- commercial advertisement.

\subsection{Billboard}

Billboard is known as outdoor advertising or outdoor sign and poster, which are usually seen on busy streets, highways, and freeways. Furthermore, the billboard is widely used in advertising communication related to non-profit causes, product marketing, and political campaigns. There are four types of billboards, namely conservative billboards, mechanical billboards, and recently developed types are digital and mobile billboards (Filiquarian, 2008). Outdoor advertising is one of the choices of time lately because this advertising media offers a lower budget than advertising on TV, but it is effective to advertise products so that product sales increase. This is supported by research conducted by (Hussain and Nizamami, 2011; Franke and Taylor, 2017; Chopra, 2017; (Dhesi, 2018); Herrera \& Pasch, 2018) conveying that billboards are very effective advertising media in introducing products amid other advertising media.

\subsection{Text}

A text is a combination of words that have meaning. It can be phrase, sentence and paragraph. Saragih, (2008:5) claims that the text is part of a semantic unit, may be realized by a sound, word, phrase, clause, sentence, or paragraph. So, texts can be found at copywriting, and it contains information about product or service that is realized on phrase, sentence, or paragraph in the advertisement. According to Gilson \& Berkmen (1980:406), copywriting there exits some types of text, namely: headline, subhead, slogan, and body copy.

\subsection{Headline}

Traditionally, the headline was considered the single most important element in advertisement. Alstiel and Grow (2007:149) stated that all forms of marketing communication use headlines, even when it is not called as headlines such as in television. There are some general practices regarding the relationship of a headline to an image, namely if the advertisement a copy story, such as an informational "how to" advertisement, the headline tends to be prominent and sufficiently compelling to goad or beckon the reader into the advertisement if the concept can be flashed more quickly as a picture message (the "one picture is worth 1000 words" rule), then the picture is usually dominant, if the concept involves an integrated headline and picture, both should probably have about the same weight.

\subsection{Subheads}

Subheads or sometimes it is called as breakers may be used to keep a headline short enough to attract attention, by giving more of the key information in a smaller but longer line 
The Dominant Speech Functions in Cigarette Billboard Texts underneath and it can break up long body copy and capsulate the important points of the advertisement. According to Alstiel and Grow (2007:163) argued subhead is in general underneath the headline, and occasionally it immediately follows the headline, as if to convey what is actually meant or wanted. The main function of the subtitle is to strengthen the headline, to clarify the main idea stated in the headline, to break up large blocks of copy, and to direct the viewer into the body copy.

\subsection{Slogan}

Slogan is defined as a short phrase associated with a particular idea, person, group. The intension is to drive the thing, person, or group whether in a statement, offer, command or even in question, for whatever goal is desired. Alstiel and Grow (2007:163) uttered that slogans are usually at the bottom of some advertisement right under the sponsor's name, a "tag" line may appear, often called a signature of slogan emotionally provocative, and this slogan becomes very meaningful to its maker. E.g. MacDonald introduces the phrase "I'm lovin' it", and Nike carry the phrase "Just do it" as slogans to encourage their characteristic products.

\section{RESEARCH METHODS}

This research project is applied qualitative descriptive method. Bogdan and Biklen (1982:30) explained that the qualitative approach is identical to descriptive. Next, qualitative research involves fieldwork in which the researcher physically goes around Medan city. Then, it is used descriptive research because this research attempts to determine, identify and describe. The target of this research is to investigate the prominent speech function by counting the percentage of the existing data. Moreover, this study is also aimed to find out not only about what categories of speech function is used in commercial billboard texts but also why it is used dominantly in the commercial billboard texts. In deep, this research is designed with single case system where it will be conducted only in commercial billboard texts done in one month. The source of data source taken in this research is the commercial billboard texts placing in the area in which there are many middle up people residing in the busiest streets in Medan. Meanwhile, the sample is only the commercial billboard texts in cigarettes advertisement. Therefore, the data gathered as the sample is only ten per cent (26) from the total number of cigarette billboard texts is 256. It is as what Arikunto (2006:131) stated that the sample is a part or as a representative of the population studied. It means that not all the population is necessarily involved in the research. Thus, the data collected will describe the accuracy of the report (Moleong, 2002:6).

Data collection is through documentary technique covering the following steps. First, the cigarette billboards texts are identified and specifically located at the busiest streets or middle up societies in Medan. Second, the data are recorded record or capture both texts and pictures of cigarette billboards. Finally, the data are transcribed by printing them out. In analyzing the data, the technique applied is a descriptive analysis to draw speech function in commercial billboard texts. Based on Miles \& Huberman (1984), the data will be analyzed through four actions, namely data collection, reduction of data, display of data, and conclusions. In the collection of data, it is attempted to collect all billboard texts without seeing whether it is commercial or non-commercial. Then, in data reduction, the researcher 


\section{Muhammad Hasyimsyah Batubara \& Dina Syarifah Nasution}

will reduce the data based on the scope of this study in which the data used is only about the cigarette billboard text. Then, in data display, the classifying of commercial billboard texts based on speech function is done so that the calculation of each speech function in each domain as the percentages will be seen clearly. And in conclusion, the result about what and why is the most dominant type which is used in billboard texts will be gathered. Then, it will be combined with the theory or previous research as the final achievement of this research.

\section{FINDINGS}

\subsection{Types of Speech Functions in Cigarettes Billboard Texts}

There were twenty-six sentences used in this research as the proportion of texts as the data sources from cigarettes domain. Then all the sentences were classified one by one so that both the type used and the most dominant one are known from the data. These following table 5 show data about speech function found on commercial billboard texts in cigarette domain. From the twenty-six texts, it is found a phenomenon in which there is no offer used, while be discovered three styles of speech function used in this cigarette domain that is statement, question, and command form. The total number of statement in this domain is eighteen. In addition, the total number of question is only one. Then, the total number of command used in this domain is seven.

\subsection{The Propositions of Speech Functions Were Included In the Table Below}

Table 5: Types of Speech Functions in Cigarettes

\begin{tabular}{clcc}
\hline No & Types of Speech & Number of speech functions & Percentage \\
\hline 1. & Statement & 18 & $69.2 \%$ \\
2. & Question & 1 & $3.8 \%$ \\
3. & Offer & 0 & 0 \\
4. & Command & 7 & $26.9 \%$ \\
& Total & 26 & $100 \%$ \\
\hline
\end{tabular}

\section{DISCUSSION}

After classifying the commercial billboard texts in cigarette domain is.

1) Statement

Dominantly apply statement in cigarette domain, because cigarette has a bad effect on health such as lung cancer, important, pregnant disease, etc. According to (Haryono and Sitorus, 2014; Al Qudri, et al, 2016) mentioned that limiting the invitation to smoke in advertisements is part of the government's responsibility for cigarette advertisements that harm consumers in the positive legal system. In line with it, the government also make a regulation such as Peraturan Pemerintah Nomor 19 Tahun 2003 about cigarette advertisement due to protect the consumers from the harmful of cigarette. It is stated in Pasal 17 that the content of cigarettes advertisement is not allowed to 1) stimulate people to smoke, 2) suggest people smoke, 3) practice how to smoke through pictures, 4) show a written text or picture in which child and pregnant woman are smoking, 5) emphasize its product as a cigarette through a written text in the advertising. Actually, that is one of the 
The Dominant Speech Functions in Cigarette Billboard Texts reason why statement speech function is the most dominant used in this cigarette domain, among others.

Further, advertising in cigarette domain has specials regulation in this country. It is base on PP 19 Pasal 14 which states that advertising of cigarettes is not allowed to reflect the product or to encourage people using the product because the product is not good for health. Thus, it one unique phenomenon in cigarettes domain, in which the content of advertisement in billboard text, never related with persuading people to smoke but it is to be remembered by the viewers or cigarette product because of the uniqueness in it. For example, the advertising Djarum Black stated that,

(1) Capucino in stick described with a cappuccino cup not cigarettes in a cup.

(2) Good sensation (Tend Mild),

(3) Cappuccino in Sticks (Djarum Black),

In choosing statement as what is shown as the examples (2) and (3) above, the company is permitted to brand the product if it is covered by the unique language so that it is easily remembered but also hide the identity as cigarette products. It is also supported by an interesting picture. Even the word and picture used in billboard texts never describe the cigarette itself. In research Abidin (2017) the design image has a significant effect on the level of cigarette purchases. Another thing that helps the advertising language is replaced with sign language (semiotic), Muhardis (2010) in his research states that images provide semiotic messages to support the marketing of cigarette products. Even, Baack (2007) tobacco advertisement must contain a statement from the dangers of smoking and chewing tobacco. It also emphaises concerning how cigarette advertising is made by using statement but with unrelated visualization.

Actually, there is a strong other reason why the statement is considered by the companies as the most effective way of promoting the product through language in commercial billboard texts. It is because the main goal of the companies when creating a commercial billboard text is how to be the strongest brand prestige so that the product can be the most imaged in people's mind among other products in the same level called as its competitor. It is as what is uttered by Baack "the goal of branding is to set a product apart from its competitors. Market researchers must seek to identify 'one thing' the brand can stand for the consumer" (Baack, 2007:41).

Meanwhile, it is impossible if the sentence saying a product is the best comes from the people at first because they have not used the product yet. Thus, the companies need to claim their own product as the best in order to hypnotize society. It means that the companies need a clear sentence as media of communication, in this case. Here is the function of language started to be used. Among the four speech function, the only statement that is able to give clear information about something so that it can be used for claiming the quality of a product, either good or service. This speech function which is used by the companies is actually as a proven of Halliday' s theory applied in this real-life through language in commercial billboard text in which the statement is proposed to inform or declare something clearly. That is why statement is used dominantly in this domain. This finding is the same as the findings of previous research on the speech function in advertising media, where statements are the dominant choice to use (Rismayani, 2011; Sibarani \& Ringo, 2017; Hafrianto. et al, 2020). 


\section{Muhammad Hasyimsyah Batubara \& Dina Syarifah Nasution}

\section{2) Command}

In addition, there is a command speech function found in this research even though it is prohibited. The company is brave in using that speech function because the content (words and pictures) of its command is illustrated by something uniquely, which is not related to the cigarette itself, such as:

(4) Go Ahead (A Mild),

(5) Start your engine (Djarum Black),

Sentence number 3 is illustrated by a girl standing in front of a sunset. In fact, it has no meaning related to the cigarette. Then, sentence number 4 is illustrated by a speedometer of a motorcycle, which also has no relationship with the cigarette itself. From the two examples, it is known that command is still permitted to be used by the company because the content is not connected with the cigarette.

While a command is less dominant because Halliday argued that command is indicated by an imperative sentence which means that it is the impolite language because it forces the viewers to consume the product directly. In addition, the two speech functions are also used because the company attempts to use different speech functions in order to groups the viewer's attention, but the content is also based on PP 19 Pasal 14 which does not persuade people to smoke.

3) Question

Then, question is used because it also does not connect with persuading viewers to smoke. The use of this speech function is applied because the company would like to use a different speech function so that it is seen as a unique commercial billboard text such as:

(6) What "News Are You"? from Class Mild.

The visualization is only a microphone and sound system which is of course not related to the cigarette itself. It is the only one sentence using question speech function. It proofs that the company would like to try an uncommon one. Also, this kind of speech function is allowed to be used because the content is not about whether the viewers want to smoke or not but just to grasp the intention of viewers in a short time to see the commercial billboard text in which there is only a slogan of the cigarette company.

4) Offer

At the final, there is no more offer used in this domain because it implies that the company offers something which is prohibited. Thus, automatically, it is never used by the company. In contrast, there is no offer speech function used in billboard text. Further, it must also be discussed by using Halliday's theory so that the cause of non- existence of offer is detected. Based on the Halliday' s theory known as functional grammar, it known that offer is speech function having two possibilities answer that is yes or no. Thus, when it used as a language in commercial billboard texts, it will weaken people to use a product by saying no in their hearts. It is because cigarette has been realized as an addictive thing which damages people's lung. So, when it is used offer in speech function, of course, the answer coming spontaneously is NO. Therefore, it needs a strong claim which does not need an answer to people as they respond. The need can only be fulfilled by a statement, not by offer speech function. Besides, there are regulation about cigarettes in this country written in PP 19 Pasal 14 , is not allowed if the adv of cigarettes promoted with offer speech functions. 


\section{CONCLUSIONS}

After analyzing the data, the conclusion is from the 26 texts analyzed. It is found that there are only three speech functions existed, namely statement: 18 (69.25\%), question: 1 (3. $8 \%$ ), and command: 7 (26. 9\%). It means that there is no offer speech function used in cigarette commercial billboard texts. In further, it concluded that statement is the most ruling speech function used in this case, proven by the higher percentage that is 69 . This shows that the use of statement is used as the most dominant in commercial billboard text, this is in line with the fundamental concept of commercial billboard text that can only be seen in 5-7 seconds, so the language used must be efficient, effective and able to hypnotize readers, so that was resulting in positive action on the item being advertised.

\section{REFERENCES}

A. L. Herrera \& K. E. Pasch. (2018). Targeting Hispanic adolescents with outdoor food \& beverage advertising around schools. Journal of Ethnicity \& Health, 23(6), 691-702. https://doi.org/DOI: 10.1080/13557858.2017.1290217

Abideen, Z.-U., \& Latif, A. (2011). Do Brand Extensions Affect Consumer Attitude: An Empirical Experience-With Reference To Pakistani Consumers. Journal of Applied Business Research, 27(2), 19-36. https://doi.org/https://doi.org/10.19030/jabr.v27i2.4137

Abidin, A. Z. (2017). Pengaruh Desain Iklan Billboard Rokok Terhadap Tingkat Konsumsi Rokok Masyarakat Kota Palu. Jurnal Online Kinesik, 4(2), 88-99.

Adelaar, T., Chang, S., Lancendorfer, K. M., Lee, B., \& Morimoto, M. (2003). Effects of Media Formats on Emotions and Impulse Buying Intent. Journal of Information Technology, 18(4), 247-266.

https://doi.org/https://doi.org/10.1080/0268396032000150799

Al Qudri, Iskandar A. Gani, S. H. (2016). Tanggung Jawab Pemerintah Terhadap Iklan Rokok Yang Merugikan Konsumen Dalam Sistem Hukum Positif. Jurnal Ilmu Hukum Pascasarjana Universitas Syiah Kuala, 4(4), 18-22.

Alstiel, T. and Grow, J. (2007). Advertising Strategy. Singapore: Seng Lee Press.

Arikunto, S. (2006). Prosedure Penelitian Suatu Pendekatan Praktek. Jakarta: Rineka Cipta.

Baack, C. (2007). Integrated Advertising, Promotion and marketing Promotion (3rd ed.). New Delhi: Pearson Education.

Bogdan, R.C. and Biklen, K. S. (1982). Qualitative Research for Education: An Introduction to Theory and Methods. Boston: Allyn and Bacon.

Cahyono, R. A. N. T. (2013). Style And Speech Function On Willingness To Buy Of Bina Nusantara University Student In Garuda Indonesia Inflight Magazine Advertisement. Thesis. Jakarta: (BINUS).

Retrieved from http://eprints2.binus.ac.id/id/eprint/28997

Carter, R. and M. M. (2006). Cambridge Grammar Of English A Comprehensive Guide Spoken and Written English Grammar and Usage. Cambridge: Cambridge University Press.

Chopra, G. (2017). A Study on the Relationship Between Customer Attention and Billboards Advertising with Special Reference to Consumer. IOSR Journal of Humanities and 
Muhammad Hasyimsyah Batubara \& Dina Syarifah Nasution

Social Science (LOSR-JHSS), 22(11), 63-69. https://doi.org/DOI: 10.9790/08372211136369

Cobuild, C. (2011.). English Grammar. Glasgow: Harper Collins Publishers.

Collins, P. (1998). English Grammar. South Melbourne: Longman.

Dalimunte, A. A. (2012). Speech Function and speech role in advertisement on television. Thesis. Medan: (IAIN Sumatea Utara).

Retrieved from http://repository.uinsu.ac.id/id/eprint/3521

Dhesi, Daljit. (2018). The Uptrend of Outdoor Advertising. Malaysia: Star Media Group Berhad. Available online: https://www.thestar.com.my/business/businessnews/2018/06/02/the-uptrend-of-outdoor-advertising/ (accessed on 9 July 2020).

Downing, Angela and Locke, P. (2006). English Grammar A University Course (Second Edi). USA and Canada: Routledge.

Filiquarian. (2008). Advertising-for-Know-it-alls. USA: Filiquarian Publising LLC.

Fitriyani, D. Z., Setia, E., \& Lubis, M. (2019). Speech Function and Process in Fake News. RETORIKA: Jurnal Ilmu Bahasa, 5(1), 1-6.

Gerot, L. and P. W. (1994). Making Sense of Functional Grammar an Introducing Workbook. Sidney: GerdStabler.

Gilson, C \& Berkmen, W. . (1980). Advertising: concepts and strategies. Toronto: New York Random House.

Grolier, A. (1992). New Webster's Dictionary. Connecticut: Grolier Inc.

Hafrianto,J. Sinar, T. S and Nasution, K. (2020). No TitleFungsi Ujaran Dan Proses Dalam Iklan Indomie Versi Arab: Suatu Kajian Linguistik Sistemik Fungsional. Madah: Jurnal Bahasa Dan Sastra, 11(1), 15-25. https://doi.org/https://doi.org/10.31503/madah.v11i1.212

Halliday, M. A. . (1994). An Introduction to Functional Grammar. London: Edward Arnold. Haryono, S. dan Sitorus, D. H. S. (2014). Perlindungan Konsumen Terkait Regulasi Pencantuman Peringatan Kesehatan Pada Kemasan dan Promosi Rokok. Jurnal Penelitian Hukum, 1(3), 117-130.

Hussain, J. \& R. K. N. (2011). Factors Affecting Consumer Attention in Billboards Advertising. South Asian Journal of Management Sciences, 5(2), 60-64.

Retrieved from https://econpapers.repec.org/article/ajmjournl/v_3a5_3ay_3a2011_3ai_3a2_3ap_3a6064.htm

Leech, G. and J. S. (2003). A Communicative Grammar of English (3rd Edition). London: Routledge.

Mahendra, Y. B. C. ., \& Zulham, F. N. (2020). The Analysis Of Speech Functions Used By An Elesp Lecturer In English For Young Learner Class. ELTR Journal, 1(1), 44-53. Retrieved from https://apspbi.or.id/eltr/index.php/eltr/article/view/49

Miles, Matthew. B \& Huberman, M. A. (1984). Qualitative Data Analysis. London: Sage Publication, Inc.

Morley, G. D. (2000). An Introduction to Systemic Grammar. Hong Kong: Macmillan. Muhardis. (2010). Iklan Rokok A Mild: Suatu Tinjauan Semiotik. Jurnal Pelangi, 3(1), 1-9. https://doi.org/http://dx.doi.org/10.22202/jp.2010.v3i1.40 
The Dominant Speech Functions in Cigarette Billboard Texts

Rismayani, N. (2011). Speech Function In Male And Female Language In Television Advertisements. Thesis. Medan: Unimed.

Retrieved from http://digilib.unimed.ac.id/id/eprint/3793

Saragih, A. (2008). Discourse Analysis: A Systemic Functional Approach the Analysis of Discourse and Texts. Medan: Unpublish.

Saragih, A. (2010). Introducing Systemic Functional Grammar of English. Medan: Unpublished.

Shanty, N. (2014). When Low Class Confronts High Class: An Analysis Of 'Petruk' Interpersonal Meaning Through His Speech Functions In Javanese Performing Art 'Kethoprak.' PAROLE: Journal of Linguistics and Education, 4(1), 24-37. https://doi.org/https://doi.org/10.14710/parole.v4i1 April.24-37

Sibarani, I.S., \& Ringo, L. S. (2017). Realization of Speech Functions in Shampoo's Slogan in Television Advertisement. International Journal of Linguistics, 9(3), 36-47. https://doi.org/https://doi.org/10.5296/ijl.v9i3.11123

Taylor, G. R. F. \& C. R. (2017). Public Perceptions of Billboards: A Meta-Analysis. Journal of Advertising, 46(3), 395-410. https://doi.org/DOI: 10.1080/00913367.2017.1334248

Wahyudihardjo, N. A. C. H. K. (2014). Presupposition and Speech Function In Women Product Advertisements. Thesis. Jakarta: BINUS.

Retrieved from http://eprints.binus.ac.id/Id/Eprint/30384

Weir, W. (1993). How to Create Interest-Evoking, Sales-Inducing, Non-Irritating Advertising. New York: The Haworth Press. 